Dellarmelin, M. L. (2020). "Old is your Grandma!": A study on clothes for elderly consumers. Consumer Behavior Review, 4(2), 84-102.

ISSN: 2526-7884

Editor: Prof. Dr. Marconi Freitas da Costa Journal's e-mail: cbr@ufpe.br
Evaluation: Double blind review

Received: March 5, 2020

Accepted: April 28, 2020

\title{
"OLD IS YOUR GRANDMA!": A STUDY ON CLOTHES FOR ELDERLY CONSUMERS
}

"Velha é sua avó!": Um estudo sobre roupas para consumidores idosos

\author{
Mateus Luan Dellarmelin ${ }^{1}$ \\ ORCID: https://orcid.org/0000-0002-6898-2341 \\ E-mail: mateusluand@gmail.com
}

\author{
${ }^{1}$ Centro de Estudos de Comunicação e Sociedade, Universidade do Minho, Braga, Portugal
}

\begin{abstract}
With the aging process of the population, it becomes essential to carry out studies corresponding to the consumption behavior of this new older generation that is part of a potential market. Therefore, the main objective of the research is to understand the process of clothing purchases by elderly consumers, identifying the main benefits and difficulties. With methodological aspects of a qualitative nature, through an exploratory type study, a focal group was conducted with elderly women. For the data analysis, the discursive practices analysis technique was implemented. Through the main results it is possible to highlight the perceptions about the specific needs in an outfit are different among the age groups of 'older' women than 'younger' women, the consensus among all, is the perception of not feeling represented by the current fashion. Consequently, the act of buying new clothes is motivated by the degradation of old clothes.
\end{abstract}

\begin{abstract}
Resumo
Com o processo de envelhecimento da população, torna-se essencial a realização de estudos correspondentes ao comportamento de consumo dessa nova geração mais velha que faz parte de um mercado potencial. Portanto, o principal objetivo da pesquisa é compreender o processo de compra de roupas pelos consumidores idosos, identificando os principais benefícios e dificuldades. Com aspectos metodológicos de natureza qualitativa, por meio de estudo exploratório, foi realizado um grupo focal com mulheres idosas. Para a análise dos dados, foi implementada a técnica de análise das práticas discursivas. Através dos principais resultados, é possível destacar que as percepções sobre as necessidades específicas de uma roupa são diferentes entre as faixas etárias das mulheres mais velhas do que as mulheres mais jovens, o consenso entre todas é a percepção de não se sentir representado pela atual moda. Consequentemente, o ato de comprar roupas
\end{abstract}


Keywords: Discourse Analysis; Older Consumers; Clothing. novas é motivado pela degradação das roupas velhas.

Palavras-chave: Análise do discurso;

Consumidores mais velhos; Roupas.

This work is licensed under a Creative Commons Attribution 4.0 International License.

\section{INTRODUCTION}

Research on the elderly consumer segment has been growing exponentially, initially, its approaches had as the main focus to demonstrate the differences in perceptions in face of multiple marketing stimuli between the elderly and the elderly (Moschis, 1992; Gonzalez; Paliwoda, 2006), inferring that there were significant differences for the realization of specific approaches between the segments.

The Global Research on Aging developed by the Nielsen Institute (2014) was conducted on five continents. Approximately 30,000 Internet users in more than 60 countries were interviewed to understand aging concerns and to assess how retailers/manufacturers of products and services are addressing the challenges of aging. The results point to three main concerns in old age, $57 \%$ to physical health, $51 \%$ to mental health, and $37 \%$ to having an active and sociable old age. However, organizations are failing to address these concerns by not offering convenience through their products and services (Nielsen, 2014).

In the same perspective, the study conducted by the Credit Protection Service (SPC) and My Happy Pocket (2018) identified that for 34\% of respondents there are few products aimed at senior citizens. The survey also found that clothing is the third item with the highest repressed demand (11\%), in addition, the fashion and clothing sector has the greatest shortage of products aimed at the elderly consumer, since, for $17 \%$ of respondents, clothing is the type of product with the greatest difficulty to consume (SPC Brasil, 2018). The difficulties are also related to the spread of fashion bias to the elderly, whether these are due to the ergonomics, colors, size of the garment or the lack of knowledge about the human aging process and the history of clothing itself (Ballstaedt, 2008). In addition, even though Brazil is the fourth-largest producer and consumer of clothing in the world with 1.5 million jobs generated, revenues of approximately US\$ 48.3 billion, (ABIT/IEMI, 2019) - the lack of products developed with the focus on the elderly consumer is noticeable.

In the international literature, some scientific researches portray the behavior of elderly women in fashion consumption (Holmlund; Hagman; Polsa, 2011), other approaches examine the role of clothing in social expression and age determination for elderly consumers (Joung; Miller, 2006; Twigg, 2007; Zhang et. Al., 2016) and also assess the influence of factors such as design and usability in the decision to purchase clothing by mature women (Das Neves; Brigatto; Paschoarelli, 2015; Au; Lam; Ho, 2016).

In the Brazilian context, research was also developed to portray the relationship between fashion consumption and the elderly (Ballstaedt, 2007; Slongo et. al., 2009; Barcelos; Esteves, 2016; Prodanov; Reinke, 2016), as well as in the identification of consumption behavior in specific groups of elderly (Machado et. al., 2016), the importance of textile comfort for clothes made for the elderly (Vianna; Quaresma, 2016) and the use of assistive technology resources (Dellarmelin; Froemming, 2019).

Based on these contexts, this research has as main objective to understand the process of clothing purchase by elderly consumers. For this, in the next sections will be discussed aspects related to elderly consumers and in relation to clothing, the methodological aspects implemented in the study, the main results and discussions, and finally, the final considerations and bibliographical list. 


\section{THEORETICAL REFERENCE}

\section{The Elderly Consumer: General and inherent aspects of clothing consumption}

Older consumers are part of a potential market and constitute a new economic force. People are living longer, and this longevity is accompanied by energy, financial resources and vitality. This is a group (mostly) willing to buy and more financially available, as there is a reduction in financial commitments to the home and family. With the expanded life expectancy, the expectation of enjoying life productively and healthily is also increased (Araújo \& Rocha, 2013).

Among the various characteristics peculiar to people who make up the third age, it is worth highlighting the issue of perceived age versus the age one feels. Araújo \& Rocha (2013) highlight that many elderly people are interested in acquiring products that could be aimed at younger individuals. This may be related to the idea that by consuming certain goods it would be possible to maintain the idea of youth. Faced with this, Ballstaedt (2008) adds that the phenomenon of aging is often restricted to changes that occur in the body, in the physical dimension. However, it should be noted that, over the years, changes are also processed in the way of thinking, feeling and acting.

In the consumer market, the elderly are not considered a strategic segment for retailers (Da Silva, 2015). However, it is now noticeable the diligence in the development of new products and services specific to this niche (Camarano, 2002; Côrte, Oliveira \& Medeiros, 2006). This demonstrates the potential and importance of formulating marketing or service strategies intrinsic to the elderly segment. Even because old age, seen as collective representation, begins - even timidly - to reveal another lifestyle for the elderly. Instead of isolation, they go out in search of leisure (dances, trips, theatres, clubs, universities) and quality of life. They are organizing themselves into movements and discussing rights (Ballstaedt, 2008).

To understand the behavior of the elderly consumer one must initially be aware that the aging process results from the dynamics of history, cultural and social contexts in which each individual is inserted and the experiences of the living space (Schein et al., 2009; Dellarmelin, Balbinot \& Froemming, 2017). The changes caused by personal maturity generate challenges in the formulation of businesses, products, services and communication to the elderly, so it is essential to have discernment about these changes and what they cause in the individual (Amaro \& Meira, 2012).

In this sense, products developed for the elderly should be made considering changes in the physiological and motor systems of these consumers. Thus, three essential criteria are needed for products for the mature market: convenience, safety and comfort (Blackwell, Miniard \& Engel, 2005). Thus, by making use of this item, the elderly consumer will be less vulnerable to possible physical, social and financial risks. As well, there are two dimensions to the development of products and services for elderly consumers. The first deals with the restriction and considers inherent needs, such as an inability to move or limited physical condition. The second dimension refers to the quality of life, attached to a healthy and active life, and provides the opportunity to expand the health of body and mind (Araújo \& Rocha, 2013).

In view of this situation, it is important to note the changes in the main financial expenditure of the elderly. In 1987, the American elderly invested more money in products and services related to medical care (Moschis, Mathur \& Smith, 1993), currently, in the Brazilian context, the elderly give more value to the desire to obtain new experiences, provided they are pleasant and rewarding (Ugalde \& Slongo, 2006), demonstrating a willingness to face life and interest in learning, either to spend time or to expand their capabilities (Neder, 2005).

In this context, where clothes are the greatest repressed demand of the elderly, clothing is understood as a textile architecture, a form of expression of the subject before the society in which he is inserted. It is a set of clothes and accessories that reveals the forms assumed by the body in the course of history, defining styles of each epoch (Castiles, 2004). This aesthetic experimentation exercises originality and the temporal axis of life becomes firm in the present, reflecting social behaviors as well as political, social and economic contexts (Ballstaedt, 2008). Fashion, as an expressive social mechanism of short duration, symbolizes the ephemeral and its goods mean mobility. Among the cycles that regulate it are novelty and individuality, it promotes rupture and shapes itself to social mutations (Calixta, Afonso \& Locatelli, 2011). The purchase of clothes satisfies 
numerous needs, such as the expression of identity and self-image, as well as the aid for mobility (Paço \& Raposo, 2003). Besides breaking with part of the tradition, fashion has introduced another dynamic to different social strata, placing as antagonistic the tastes for differentiation and imitation, the preferences for rupture and conformism, for what is proper and collective, for the desire to differentiate from others and belong to a social group. When a new fashion emerges, anyone with enough taste and resources can conquer it and exhibit it (Calixta, Afonso \& Locatelli, 2011).

Therefore, according to Paço \& Raposo (2003), clothing represents an important symbolic area of consumption. Assessing the level of disposable income, some consumers will spend more on clothes, which in itself already reveals something about them. This often fits into a set of products used by individuals to define, communicate and represent social roles. Therefore, due to market trends, the clothing industry must adopt a market orientation. Faced with this assumption, there is a need for continuous consumer research, i.e., the identification of the target market to be able to direct marketing efforts to well-defined segments (Paço \& Raposo, 2003).

Moreover, in fashion for the elderly there are various forms of prejudice, whether these refer to trends, ergonomics, colors, sizes of clothing. This feeling, propagated by the lack of knowledge about the human aging process and the history of clothing (Ballstaedt, 2008). Another indicator of historical prejudice about clothing for the elderly refers to the type of clothing determined by women and men. The clothes "suitable" for elderly women of the 1930s should be longer, with dark colors, characteristic of these, to identify the pieces for "grandparents", besides the classic white and grey crochet shawl (Ballstaedt, 2008). For men, the continuous use of a suit, consisting of a jacket, vest and trousers of the same material and color, being used on several occasions since the XIX century (Catellani, 2003).

It was only in the 1960s that clothing trends directed to the public in this segment began. Bold was the subject who disrespected the rule of wearing clothes according to their age group, this individual, who would be poorly seen in society, because there were sudden differences between clothes for young and old (Ballstaedt, 2008), and through these distinctions instituted in society, at that time, the prejudice regarding the dress of the elderly, is perpetuated to this day (Gonçalvez, 2002). However, the jovial spirit as an element in the fashion market was instituted from the sexual independence obtained with the advent of the contraceptive pill, being the fashion made for young people (Palomino, 2002). At this time, youth is experienced as an entity endowed with the power of a market of its own (Baudot, 2002), and it is necessary to be and appear young. It was only in the 1990s that people began to have the perception that one day they would grow old (Embacher, 1999).

The perception of the aging process is inevitable to all human beings, being identified by intraindividual modifications, such as variations that affect the curvature of the spine, the abdominal circumference, the movement of arms and legs, being influenced both by habits during life and by the aging process itself (Tilley \& Dreyfuss, 2005).

The elderly are breaking paradigms and moving away from the image built by modern Western society related to old age is synonymous with loneliness, disabilities, sadness. The elderly are seeking their place in society and challenging themselves to maintain their independence (Ballstaedt, 2008). These changes in the behavior of the elderly are observed under the construction of a new social role, leaving to the past, the conception of being home-made, adopting postures of a more active social life, traveling, appropriating information and communication technologies, performing personal care through aesthetic treatments and gyms, besides consuming more fashion products that demystify the old prototype of old age (Fisher, Vícter \& Teixeira, 2009).

In this sense, it is perceived that the market is not prepared for these consumers, as there are no products adapted for the elderly respecting their differences and limitations (Gomes \& Lüdorf, 2009), and organizations must understand these factors. Given this perception of the market's shortcomings in offering specific products and services to the elderly, Slongo et al. (2009), list the lack of specific stores for this segment, and it is a challenge to choose whether or not to create stores that serve only elderly consumers. It is noticeable that most of the clothes available in the market are discreet and neutral, without transparency or necklines. Seduction is absent, nothing is intended to accentuate curves, but rather disguise (Ballstaedt, 2008). 
It is necessary to develop new products, specifically clothing, for these consumers who find in the market many difficulties and limitations relevant to their age group (Tilley \& Dreyfuss, 2005), offering the elderly themselves the opportunity to express their image and identity, because Brazil is heading towards this new universe, in the gradual expansion of the economic strength of the elderly consumer market (Ballstaedt, 2008).

\section{METHOD}

This research is characterized by the qualitative nature of the data. The technique used is the focus group technique that uses group discussion sessions, centered on a specific topic, debated among the participants, who are stimulated to talk about their motivations, feelings about the product, experiences of purchase and use (Debus, 1994; Ressel, 2008). The focus groups consist of 8 to 12 people involved in a discussion led by a moderator who stimulates consumers to expound on the topic in a deeper way (Flick, 2013; Cooper \& Shindler, 2016). For the selection of individuals who participated in this study, we based ourselves on the indication of National Law no. 10,741 of October 1, 2003, which considers elderly, every individual aged sixty or over (Brazil, 2003).

In this sense, a focus group was conducted with elderly women only. For the selection of participants, the snowball sampling technique was used (Noy, 2008), in which one elderly woman was invited and she invited another and so on until the minimum number of eight subjects was completed.

In this study, the data collection technique used was the focus group, based on a semistructured script and a form with basic information (socioeconomic), opportune to be self-filled by the elderly consumer or with the help of the researcher. It should be noted that at the beginning of the group the Term of Free and Informed Consent (TCLE) was read, the objective of the research and the request for authorization for audio recording and photography of the dialogues were presented. The semi-structured script was developed based on two blocks, being these, i) purchase process and ii) types of clothing for elderly consumers, their benefits and difficulties. The semi-structured script was sent to a professional specialized in qualitative research, with a Ph.D. in Administration, who made contributions regarding the structure of the script, the approaches of the questions and readjustment of the blocks to assist in the analyses. Besides the validation with a professional in the area, a focal test group was carried out, with eight elderly women. After this group, some modifications were made, mainly in the formalization of the terms used, facilitating the understanding by the research subjects.

In block 1 of questions in the script for the group, the questions refer to the purchasing process, developed to identify the main reasons for the purchase of clothes, the frequency of consumption, the means of communication used, who are the subjects who make the purchase and the willingness to pay for the clothes. The questions defined in this block are presented in table 1:

\section{Table 1}

Block 1 of questions: the process of buying clothes

1 - What is the reason to buy clothes? How often?

2 - What means of communication do you use daily? And which ones do you usually look for information about clothes?

3 - Do you usually go and buy clothes by yourself? Does anyone accompany you when you go shopping?

4 - How much do you usually pay for any piece of clothing? Would you spend more?

Source: Prepared by the authors (2020).

After obtaining the basic information inherent to the consumption of clothes, block 2 addresses themes related to the perception of the meanings of fashion and clothes, the difficulties and perceived benefits, and the suggestions of adaptations of the clothes to the elderly consumers. In this sense, table 2 describes the questions in this second block. 


\section{Table 2}

Question Block 2: Types of clothing for elderly consumers, benefits and difficulties

5 - Do you feel represented by the current fashion? What does clothing mean to you?

6 - Do you prefer clothes to put on and take off? Why? What should be done to help with handling?

7 - What do you look at first in an outfit? How do you choose it? What are the advantages/benefits of the garments for you? And the difficulties?

8 - What kind of clothes would you not buy?

9 - When you talk about old people's clothes, what do you think?

10 - What is missing in your clothes for your age? What should aesthetics be like?

Source: Prepared by the authors (2020).

In this context, the analysis process aims to extract meaning from the data collected. It begins with preparing the data for analysis, deepening the understanding and representation of the data, and carrying out an interpretation of the broader meaning (Rossman \& Rallis, 1998; Creswell, 2007). Therefore, in this study, for the analysis of qualitative data, a linear, hierarchical approach was used, being more practical and interactive among its several interrelated stages (Creswell, 2007, p. 218). Therefore, first the data were prepared for analysis through the transcripts of the information generated in each group (male/female), organizing them and preparing them for separate analysis. Later, a complete reading of the manuscript was performed to obtain a general perception and reflection on its meaning (Creswell, 2010). After these steps, from the codification, detailed analyses were performed, in which the raw material was organized in blocks to assign meaning to the information (Rossman \& Rallis, 1998; Creswell, 2010). It should be noted that in this coding process, such blocks are characterized as i) purchase process and ii) types of clothing for elderly consumers, the benefits and difficulties.

Finally, the interpretation and extraction of the meanings of the data was performed based on a questioning approach, through the analysis of the discourse that aims only to analyze the meaning of the discourse, making a reading focusing on the discursive position of the subject, concerned with understanding the meanings that the subject manifests through his discourse, being its focus, the meaning and not the content (Creswell, 2010). The material for discourse analysis refers to the empirical/experimental corpus, since the material was built exclusively for research, through the groups. In addition to the fact that, in discourse analysis, interests are in the texts themselves, instead of considering them as a means to "reach" some reality that is thought to exist behind the discourse, be it social, psychological or material, in addition to examining the way language is employed, one must also be sensitive to what is not said, demanding an improved awareness of social trends and contexts (Gill, 2015).

\section{RESULTS AND DISCUSSIONS Profile of older women}

Eight women members of the same meeting group from the third age of a town in the interior of Rio Grande do Sul (Brazil) participated in the focus group. In these meetings, they meet to carry out various socio-educational activities, physical activities, deliberations of trips to tourism or dance meetings that take part every weekend in the region and the expenses of money collected or received from the public authorities. First of all, after the researcher reads the information in the Term of Free and Informed Consent and explains the objectives of the research, the elderly women answered a questionnaire that portrays the basic information inherent to their profile. In this sense, in table 3 , we present the biological age and the cognitive age of the eight research participants. We chose to name them fictitiously to maintain the secrecy of the identities as combined with the elderly. 
Table 3

Biological age and cognitive age of focus group participants

\begin{tabular}{cccc}
\hline & Biological Age & Cognitive Age & Occupation \\
\hline Sophia & 76 years & 60 years & Retired Farmer \\
Alice & 88 years & 88 years & Retired Farmer \\
Julia & 82 years & 82 years & Retired Farmer \\
Isabella & 67 years & 22 years & Domestic Retired \\
Luiza & 61 years & 50 years & Retired Teacher \\
Valentina & 70 years & 60 years & Retired Saleswoman \\
Helena & 69 years & 40 years & Retired Cook \\
Agate & 75 years & age 65 & Retired Confectioner
\end{tabular}

Source: Prepared by the authors (2020).

It is first analyzed that participants who are 70 years of age or older assign their cognitive age closest to or the same as the biological age group. Elderly women between the ages of 60 and 69 attribute their cognitive age from 11 to 45 years less than the biological age. This factor has a direct relation with the way of looking at life, thus portraying that women at the beginning of the third age have a more graceful vision and face age with fun, unlike women with higher ages, who due to the limitations are denser, face old age in a difficult way because they lose their independence.

As far as schooling is concerned, six of them have incomplete high school, for the reasons of having to help in the maintenance of rural properties, since the income comes entirely from agriculture. One interviewee completed high school and only one completed college. It should be noted that the two participants with higher education, allude to lower biological ages than the others and did not work in agriculture.

The range of monthly income per capita of the participants is $R \$ 1,577.00$ to $R \$ 2,364.00$ for three of these, from $\mathrm{R} \$ 2,365.00$ to $\mathrm{R} \$ 3,940.00$ also for three elderly women and from $\mathrm{R} \$ 3,941.00$ to $\mathrm{R} \$ 4,728.00$ for two women. It is noticeable that all of them have an income higher than the regional minimum wage which is $\mathrm{R} \$ 950$ and also above the average value of the pensions paid by the National Institute of Social Service which is $\mathrm{R} \$ 945.80$.

All the older women have children, six of them have up to five children and two have from 9 to 11 children. Despite this, four of them live alone, two live with their partner and one lives with four more people. It should be noted that two women living alone, the family has hired caregivers who spend the night in their homes due to functional and physical limitations. We asked them how many have the house or some piece (kitchen, bathroom, living room, bedroom) adapted for their age and only one indicated having the bathroom adapted with bars on the walls that help during the bath and next to the toilet. In addition, one of the elderly women already uses one of the products with the use of assistive technology, the cane, which is the hand support to move around.

We also ask them how they consider their style in relation to the consumption of clothes, and for four of these, the style is defined as traditional, because they do not like to dare or clothes with very attractive colors, they prefer to be unnoticed. It is noteworthy that of these four traditional women, three are older than the others. Three elderly women consider themselves modern, they believe they are up to date with the latest clothes, they love to combine different colors and different models, they like to dress up and they frequent beauty salons frequently. One elderly woman considers her style romantic, loves clothes with lighter colors and flower prints, because she considers herself passionate about life.

All the old ladies enjoy retirement. When asked what they like to do most, they were quoted from domestic service, playing cards or bingo with their friends, playing with their grandchildren, tidying up the flower shop at home, and the most quoted was that they like to go to dances and have 
fun on weekends. Again, it is highlighted that older women with lower ages, have preferences for activities beyond those restricted to the residence.

Finally, the participants scored on a scale from bad to great, as they consider their state of health. Four of them consider their health status as regular, these elderly women are of a higher age and their preferred activities are restricted to the domestic environment. Three elderly women consider their health status as good, and only one considers their health status as optimal, this being the woman who has been retired for less time than the other participants in the study.

\title{
Perceptions of clothing consumption by older women
}

\section{Block 1 - Purchase Process:}

To begin discussions with the eight elderly women, we asked them what would be the main reasons to buy some clothes and how often they buy them. Immediately, the answer "I buy clothes when I feel the need for new clothes and also to look beautiful" (Luiza, 61). Adding to the story, Valentina (70) says that "I usually buy clothes at the beginning of the two main seasons, winter and summer, because then I can wear them, my size varies a lot throughout the year". Sophia (76) also reports that "I only buy when I need to, without necessity we don't. And I usually buy a few times a year, more when there are fairs or good discounts".

The act of buying clothes only when necessary, is defined by the elderly as realizing that the current garments are no longer suitable, in terms of the size of the garment fit, if the garment has some seam fault or if the fabric has torn. Ágata (75 years old), complemented: "I like to buy only when I need it, and I like clothes just as I am today, I feel good". It is noticeable that the old lady wore a black and grey colored suit, the model of the trousers is the tactel and the shirt has a cut on the neck, with short sleeves, unique color, besides having a black coat on the chair. When we noticed the behavior of the elderly women in buying new clothes only when they feel the need, we questioned them the origin of this habit and Helena (69 years old) told us:

\begin{abstract}
"Ah, I usually buy three times a year and look there, I'm not a big fan of keeping a lot of things, use, use, until it becomes almost a floor cloth (laughs), people get sick of seeing me in the same clothes, but I'll do what, I don't have that kind of money, We Germans are used to wearing a lot of clothes, and have few pieces, one to work on the farm, one to stay at home and a tidier for when there was a kerb (German ball, our translation), or wedding, birthday and Christmas. Then we grew up and continued doing that, buying very little. But my daughters are already very different, they buy more clothes than they can (laughs)".
\end{abstract}

In this discourse we can analyze the cultural influence as a factor for the consumption of clothes, the habit of having few pieces, only for special occasions, was passed on by the generation of the parents of these women, and it is also analyzed that this type of behavior did not influence the generation of the children of these elderly women, as reported in this fragment of the discourse: "my daughters are already very different". We infer then, the subjective existence of buying new and more clothes, however, the act was not affected by the influence of cultural variables, which reminded them to invest this money in another area considered more adequate or essential.

Isabella (67), who attributes her cognitive age to 22 years old, has a different behavior in relation about the other elderly women in the group, she reports that "[...] I like to buy clothes so that people can see me in other clothes than what they usually see me in, always very simple, but it is to be presentable. Where you've seen, people have to see me in cheerful, colorful and alive clothes, so I show the city that I am a very happy woman. Every month I buy a little something here, a little something there". In this speech of the elderly woman, it is noted that clothing becomes an instrument of reconstruction of her identity, it is through these pieces that she expresses her feelings before life and 
the community, so keeping the frequency of consumption stable is inevitable for the maintenance of this adopted identity.

As with the reasons for buying clothes, the means of communication that are used daily by the elderly also remain, for the most part, habits created years ago. All elderly women had access to television only when they were already adults, even when they already had a family, as we noticed in Sophia's speech (76 years old):

"My husband and I bought our first television in 1974, at that time it was like a luxury item today. But we watched television only at night, because we spent the day working in the fields, and then, when night came, everyone took a shower and had dinner together, and then we all went to the front of the television to watch the newspaper and watch the soap operas, we also talked a lot, it was a moment that we managed to stay together with the whole family together. You can have a little fun and I need that, because nowadays, everyone has their cell phone, my children, my grandchildren, nobody pays attention, it's as if everyone has a TV in their hand".

All the elderly women agreed with Sophia's speech and remembered moments with their families, in this sense, it is reinforced that television played an important role in uniting families. Besides television, radio is a means of communication used by women. Julia (82) reports that "I have the radio on all day long, it is like a company for people who are alone during the day. If something happens we already know and also because they say the promotions of the market and some stores, then we already know where it is cheaper to go there to buy". The use of this medium is reinforced with the report of Ágata (75 years old), "I like to listen to the radio, especially in the morning, there's always news about what's happening here in town and also in the region, besides having some very cheerful songs that you can dance while doing the service". As far as the media is concerned, the most commonly used by the elderly is television and radio. It is not possible to make inferences about the search for information about clothes, because the elderly are passive about information. As reported in Julia's speech, it is through the radio that they listen to the promotions carried out in the city's stores, which directs them to the act of buying clothes.

We ask them if they usually go alone or with someone when they buy clothes, how much they spend and if they would spend more. Valentina (70) reports that "I like to go and buy clothes with my granddaughter, usually when my granddaughter stays with me in the opposite shift of school, I take her along, then she always helps me to choose some pieces, but of course, I decide in the end". In contrast, Luiza reports that: "I go alone, if I like it, I buy it, if not, I don't buy it. Because then you take the opinion of others and end up buying on impulse, but comes home, will put and no longer likes, does not see some details that with vendors talking or grandchildren putting pressure to buy, then it is money out". While some elderly women prefer to go shopping with someone else and others alone, Helena (69), reports that "I like to pick up my clothes on parole, take them home and try on at home, so I can think better and see if I want to, then my granddaughters can also help by saying whether it looks nice or ugly".

As for spending on clothes, the elderly also divided into two opinions, four of them, agreed with Julia's speech (82 years old): "I wouldn't spend more on clothes if I could, I like to buy something to eat for the family, because as soon as we were raised". And, the other opinion is reported by Luiza (61 years old): "it is difficult to find some clothes here in city that are beautiful and the ideal size below a hundred reais, so we buy, since we do it every once in awhile, then we can buy, if not, there is no way, we pay little by little". Isabella (67) adds that "it depends on the clothes we pay more than a hundred reals, but usually we don't pay much for clothes, because that's not enough for medicine, light, water and food". Another elderly woman who agreed with the statement of spending more than a hundred reais when buying clothes is Valentina (70 years old), who added, "I bought a few things in the store and gave more than four hundred reais, my God! I was scared, but I'm paying a little bit a month, so I'm getting it". The old women's speeches show that opinions are divided between those who spend more 
than a hundred reals and those who spend less, as well as those who are divided when it comes to buying clothes alone or with others.

In closing the discussions in this block of questions and analyses, we present briefly, through table 4 , the main findings inherent to the preferences of elderly women in the purchasing process.

\section{Table 4}

Overview of elderly women's preferences in the purchasing process

Purchase of clothes out of necessity from the degradation of old pieces;

Intergenerational influence inherited from parents for low consumption of newclothes;

Others buy clothes for identity maintenance;

Means of communication to follow the promotions: TV and radio (preferred for local information);

They are divided into preferences for buying alone or accompanied;

Buying with the "conditional" option is a relevant attribute for the purchasedecision;

They are divided between those who like clothes better and those who consider this type of secondary

expenditure.

Source: Prepared by the authors (2020).

\section{Block 2 - Types of Clothing for Older Consumers: Benefits and difficulties}

When we start this block, we ask them if they feel represented by current fashion and what clothes mean to them. Alice (88), started reporting that "I don't feel represented by the fashion I usually see around. It's very modern in things, I like more traditional and simple things, it's very 'Frische' (an expression used in the German dialect, used to represent the term 'full of freshness' / our translation). By complementing the old woman's speech, as far as fashion perception is concerned, Luiza (61) complements:

"I don't see myself represented by fashion, because this way, I see that they always use those young women with very beautiful and healed bodies, I have never seen a clothing commercial with women like us, fat, old and with gray hair, even because when a younger actress dyes her hair in white it's beautiful, but when she's an old woman, then it's ugly, I can't understand it" (Luiza, 61).

In the speech of this interviewee, the fact that the young body continues to be the protagonist of the media is analyzed, especially in clothing commercials, in this sense, as Simone de Beauvoir (1990) describes, the woman is the most affected by old age, because when young, the body is seen as a sexual object, already when old, her body is no longer desired, that is, an old body becomes invisible. Complementing this perceived reality, Isabella (67) adds:

"I believe I'm not represented by fashion. Because what I see these clothes and in the women is a lot of piriguettes (slang in the portuguese language that describes a woman who shows interest in other people, even if the other person is in a serious relationship / our griffon), I do not like that, in my time the clothes were beautiful, with different cuts and good fabrics, which covered the body but had a charm that men were enchanted. I remember a light blue suit that I had, loved! (sighs), I wore it to go to the dances, I had lace on the front and wore it with a white blouse underneath, I could put a chain on my neck. She looked like an important woman (laughs)" (Isabella, 67 years old). 
In the discourse of older women, it is analyzed that they believe that fashion is made for young women and they perceive this fact, even in stores, when they look for clothes for themselves. This suit is reported by Helena (69) and Ágata (75):

"I think most of the clothes you have, at least in the shops here in town, are made or sold more to young women. We don't like so many prints, so much shine, like, these clothes attract a lot of attention, not to mention those that stick to the skin, we (indignation intonation), it's very ugly, it marks everything, and there's still a woman that wears to go out, it's ugly, very ugly" (Helena).

"That even we who like to wear a blouse, a skirt, a pants, a blazer and not those little dresses above the knee that appear almost everything. The clothes have to be very comfortable, simple and beautiful, with bright colors, happy, because when we get to a certain age, what matters is only the comfort, the rest we don't pay much attention" (Ágata).

In this sense, it is noticeable that elderly women do not feel represented by fashion, a factor that, when added to the cultural influences of not having the habit of buying many pieces of clothing, determine the behavior of these elderly consumers in not using clothing as a factor of expression and maintenance of identities, being clear and noticeable through the speech of Sophia (76 years old):

"clothing serves more out of necessity, as we have already told you, we were used to having few pieces, specific to places we would go, so clothing is more need and comfort."

After the questions regarding the perception of the representation of fashion by elderly consumers, women were asked to comment on when they go to a store, when they find the clothes, what were the difficulties and what improvements should be made to benefit. Julia (82 years old), starts saying that "clothes have to be easy to put on and take off, because when you get old you don't have the same strength as when you were young, everything falls and gets harder (laughs), so it's a bad way, you've seen it, it starts hurting". Adding the statement, Helena says: "besides being easier to put on, the clothes have to be easy to wash, because my back is weak, so I prefer the clothes with fabric that they wash in the machines, I wash only under the arms with soap that I do at home, it is hygienic and the machines can not wash these little parts". Besides the information described by Julia and Helena, the participant Ágata (75 years old) reports that:

"I always buy 'like this' clothes, a blazer that is open, easy to put on and take off, so if I want to close it has the buttons, underneath a blouse that is large and loose, then I can put it easier and leave the neck sample, you can combine with a chain. The pants have to be looser too, because I have to wear them just sitting down, and I get a little dizzy if I have to lower my head too much, then to close there's a zipper and a button, but there could be only one button, it's easier to open than a zipper, even more, it breaks, so it's tight, in a hurry, and still old, you've seen it (laughs)".

From Ágata's speech it is possible to perceive the first inferences regarding the difficulties arising from the physical limitations that the third age has on elderly women and in what way they affect the act of dressing, difficulties that Valentina highlights: 
"I have a hard time putting my clothes on, because years ago I fell at home and hurt, so it always hurts to put clothes on, I try to put them on, but most of the time I have to ask my daughter for help when I am more tired or in more pain. I only try to wear blouses that have a button, because the blouses that you have to take off by raising your arms, my God (the face of pain), is horrible, and at my age, it doesn't even work anymore, it gets worse" (Valentina, 70 years old).

Analyzing these speeches, it is possible to notice that there is a need to adapt the clothes to help in the handling of the piece, mainly for the act of dressing and undressing, both in what refers to blouses or pants. It is also noticeable that the physical limitations are the main complaints of the elderly women in the difficulties of the relationship with the clothes, besides that, they need help from other people, losing little by little the autonomy in the act of dressing, as said by the participant Luiza (61 years old), "age makes us slower in the movements and we know that it will be like this with all of us and every year we will feel it more and more".

We also question them, how they choose their clothes, what they look for first and what the perceived benefits and difficulties are. Alice (88) began by saying that "when I go to a store, I first look at the models that it has of what I am needing, then I look at the colors and size, and I look if there are no defects in the seams, because I have already bought clothes that soon opened the seams". Besides identifying the models, colors, and sizes, Ágata (75 years old) adds that "I look directly at the fabric, if it's easy to wash, if it doesn't have a tear, if the ink can come out soon and then I look at the cut of the garment, it has to be simple, nothing fuzzy", a statement that the other elderly women agreed with. Another way of choosing clothes is reported by Valentina (70), besides the difficulties perceived by the participants Luiza (61) and Helena (69):

"I look if you have the number I need, then I look at the other things, but I don't like to buy the first outfit I see, I always go to other stores to see if it's prettier or cheaper. But, above all, I don't like the saleswomen saying that everything is beautiful for me, I like to look alone or with my granddaughter who won't lie to me if the clothes look ugly" (Valentina).

"I've never seen clothes in the shop windows that are like this, for more chubby people, or that we can wear, it seems that they only want the little girls that come in and buy, besides, there are few clothes that don't have a tear, fringe or something like that, this is for young people, I'm an old woman, I can't wear this, it's ugly" (Luiza).

"It's hard to find an outfit that's easy to put on and take off, so I particularly look for some piece of clothing that's looser, I often buy a number above mine, because then I can pull it off and put it on without anyone's help" (Helena).

It is noticeable that the greatest difficulty reported in the speech of the elderly women is about the size of the pieces, being necessary, until buying a larger number than they use so that they can make the exchange without help from other people. Besides that, the style of the clothes, are considered very jovial. One of the elderly women also reported:

"When I go to a store it's much harder to find an outfit for me than for my partner, men don't have many options, it's that and that, women already have a lot, but a lot of things. It's harder for me because I can't find the right size or model that I like" (Luiza). 
The fragment in which the elderly woman reports that it is easier for men to find the clothes they need because they do not have many options, participant Isabella (67) added to Luiza's speech:

"It's much easier for men to find clothes, because they wear anything you buy and it's not very flashy, for women there are many more models and options, that leaves us lost too, and yet there are some women who dress badly, with those miniskirts or shorts very short that appear the ass, ugly thing!" (Isabella).

It is analyzed through these speeches that women feel more charged about the type of clothes they wear and the amount of options they have to consume, but it is the women themselves who criticize other women the most, besides indicating that they believe that men care less about their physical and health in comparison with their concern.

Still about the diversity of clothing options that consumers find in stores, we then ask them what kind of clothing they would not buy. The participant Helena (69), began by describing that:

"The kind of clothes I wouldn't buy are skirts, miniskirts (all the old ladies laughed a lot). Very low-cut blouse. Those pants you've been tearing, gosh, it's very ugly, imagine me, if I go to a dance with that they'll think a cat scratched me (laughs). I don't like chickens much either. Pants too tight (like skinni) and shiny, I don't like it" (Helena).

The other elderly women agreed with the types of clothing Helena listed and corroborating with the speech, Ágata (75) complemented by describing:

"I understand that nowadays it is more different clothes for women than in our time, for example, we had few clothes, usually one for work, one for social events and one to go to church. I see my daughters who are working today, they have a lot of clothes, like one for every day of the week, shoes then, my goodness! Bags too, I have one for about ten years, she (daughter) must have one for every month (laughs)".

In this sense, one can perceive through the speeches of the elderly, resistance to the current styles made of clothing, escape the traditional pattern that most prefer. When classifying such clothing as for younger women, we asked the older women interviewed what they thought when people talked about old people's clothing. In this item, two opinions divided the women interviewed. The first opinion, that they perceive this classification of clothes for old people is reported by Isabella (the cognitive age indicated by the participant is 22 years old), with the following speech:

"There is a distinction between old clothes and new clothes. For example, young girls' clothes are cheerful, colorful, have different cutouts and models, but for me as a family lady, there are only those things that seem to advertise that I am an old woman, and the models that fit me are black, grey, brown. Besides, if I'm going to wear a flashy, shiny or fringe outfit, they'll say: that old lady is crazy, it's very sad" (Isabella, 67 years old).

The second opinion, that people do not or do not realize that they classify certain clothes for old people, is run by participant Alice ( 88 years old) and complemented by participant Julia ( 82 years old):

"I don't think they talk about old people's clothes anymore, everyone wears what they want and what they like, we can go into the store and 
buy what we want, if we're paying, we can buy what we want and in the way we want" (Alice). Julia added: I always buy cheerful clothes, of course, but more normal, more traditional".

An important detail in this factor that can be analyzed is that the elderly women who agree with the statement of not perceiving distinction in old people's clothing, wear similar garments, shortsleeved shirts with a circular collar or closed neck opening, all wearing dark trousers, white, brown and black shirts, besides being the 'oldest' elderly women in the group. In this item, we classify this behavior as a contradiction between the discourse and what is seen, since the elderly women themselves had a similar pattern of dress. One of the participants reported an event concerning the distinction of clothes for old people:

"I've never felt any restriction or that there's any distinction in clothes for the elderly, but a friend of mine (65) from Porto Alegre told me that once when she went to a mall, that's what she's skinny and very chic, she went to buy a pair of pants at a brand store, and says that the saleswoman kept looking at her with a face like 'what does this old lady want with this style of pants' and left the store upset with the situation, because she prefers these stores because the pieces are more unique, they are not made in piles as it comes here" (Helena).

Although different opinions on the perception of the existence of clothes classified for elderly people are different, or that an example is used with other people from their social life who have experienced scenes of prejudice, we question them, what would be missing then, in the clothes for their age and how should be the aesthetics. Participants Julia (82) and Sophia (76) list the clothes they should wear:

"Clothes should be more neutral, easier to put on and take off, with more size options, simpler prints, more colorful. Never shine. You have to have more buttons than zippers, sometimes you have to push them, you don't have much anymore" (Julia).

"There are pants and blouses for example that I can't wear because they look like my granddaughters wear, so I try to find some that are more different, without so much glare or design, very simple, but it's hard to find something more traditional, because the shop owners who used to buy the pieces have retired and don't work anymore, so the new ones don't think about customers like the people who are more common" (Sophia).

In these two speeches, it is noticeable that the traditional style is the most preferable for these elderly women and the lack of this type of piece in the stores, also, they list the preference for the buttons instead of the zippers, making the handling of the pieces easier. In sequence, participants Valentina (70 years old) and Alice (88 years old), analyze the context for the use of clothes:

"Oh my son, after a certain age one only cares about the comfort of the clothes, does not think much about their beauty. There is nothing more important than the comfort of the clothes on my body. I will never buy a garment that is not comfortable again, it has to be wider, the fabric cannot be so warm, because people who suffer from menopause, feel a lot of heat, then some clothes make you even warmer. I'd much rather wear a loose blouse underneath and a jacket with buttons on the front, so when you give me the warmth I can take off the jacket and leave it 
on, but it has to be an open collar to get air. It's hard to find matching clothes and more colorful too" (Valentina).

"I agree with the neighbor, besides that, if we have to choose between being prettier with the clothes or feeling more comfortable, certainly the comfort, because I'm 88 years old, I can't put on and take off some clothes anymore, so I have to take care of that, because I don't like to have to ask for help to put on something, that I don't like being old. The clothes should come helping us who are older, but they don't think much about us or nothing has arrived here yet" (Alice).

In these fragments of discourse, the elderly elucidate their preference for comfortable clothes, this being the most relevant attribute. It is also perceived that it is the older women who have the comfort of the clothes as the main factor. Again, the need for larger sizes, preference for buttons and more colorful pieces, items that were also previously mentioned by the elderly women Julia and Sophia, is also specified, the need for fabrics that are so warm and favor sweating and more open collars, so that the perception of heat caused by menopause is softened. Some modifications and perceptions about specific pieces of clothing, such as pants, blouses, and dresses were reported by participants Luiza (61 years old) and Isabella (67 years old):

"I think the pants should be a little wider, the dresses longer, that go under the knees, with a flower print, colorful, with very bright colors, very cheerful and that somehow you can put it on and take it off from the front, not with a zipper on the back, then you always have to have help from someone. There are also the shirts, as it is very hot here, they have to be wider and with fabric that does not get too hot, but it must also be cheerful" (Luiza).

"In my vision, one of the problems I find is, for example, that I have a lot of flaccidity in my arms, look here oh (demonstrated in the arms), there I can't with alky clothes, then, the shirts, dresses have to be a little longer in this part, to hide and not appear so much (laughs). Also, the dresses have to be a little looser, mainly in the belly part, because if it doesn't mark much below the breasts, the model can be bigger but that leaves the waist curved, very pretty, from there" (Isabella).

These elderly women emphasize the need for adjustments as to the sizes of the pieces of clothing to be larger, as well as to be looser so as not to mark the body so much. It is also inferred the concern with the aesthetics of the pieces, suggesting more vivid colors, cheerful. Also, when analyzing the speeches of the elderly women when questioning them about what would be the necessary modifications in the clothes for their age, again it is possible to classify them in two segments, one of them, the elderly women who prefer traditional clothes, which are used to wearing, without extravagances, their concerns are conditioned to the comfort and usability of the pieces. The other group, composed of the elderly women who consider their cognitive age well below their biological age, besides suggesting modifications in the model of the piece, are concerned with the aesthetic look, which is cheerful and transmits to other people a positive state of mind. The main findings of this block of questions and their analysis are indicated in table 4.

\section{Table 4}

Overview on the elderly and types of clothing: benefits and perceived difficulties

- The elderly do not feel represented by the current fashion;

- They believe that fashion is made for young women;

- The media and stores are focused on young customers; 


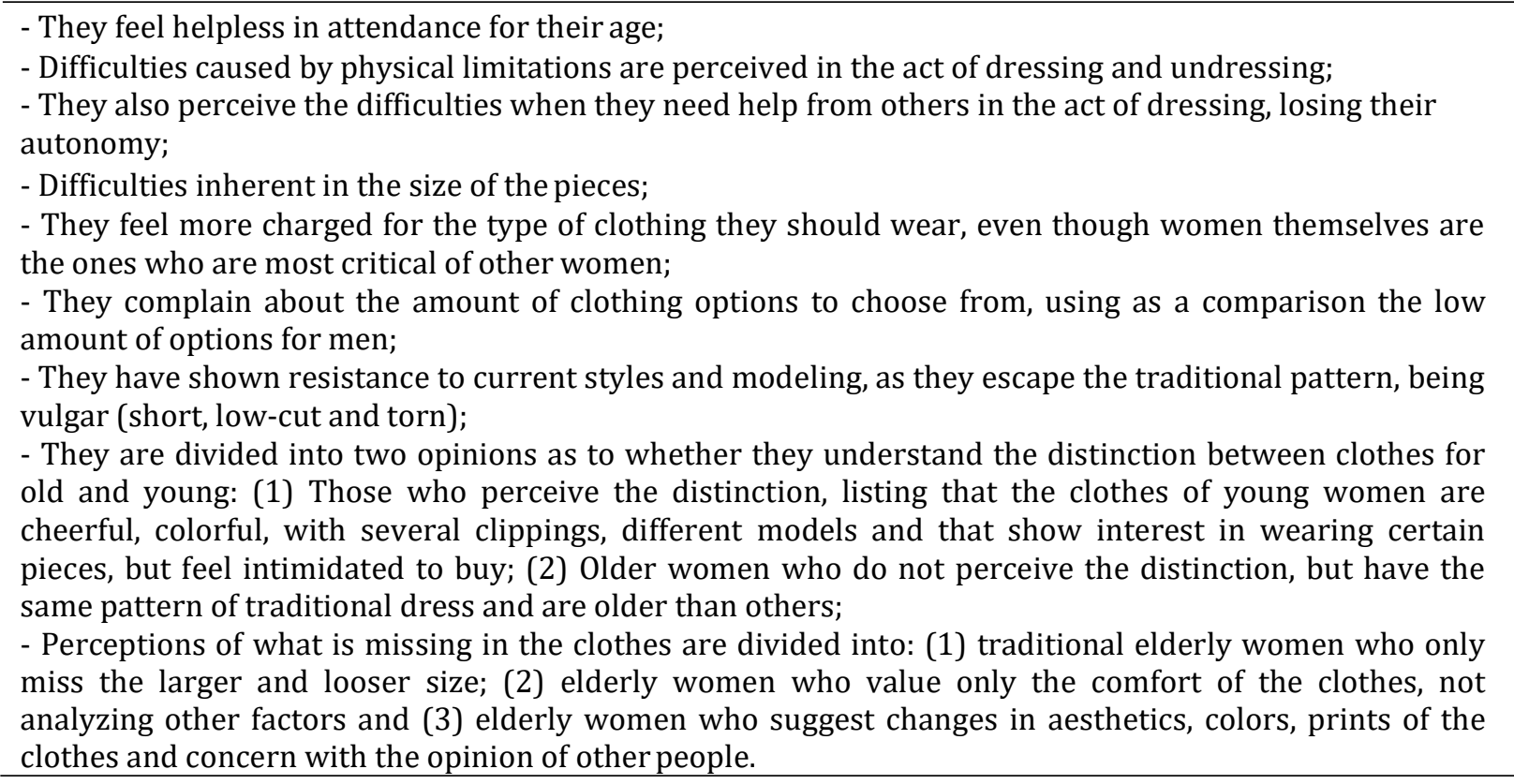
Source: Prepared by the author (2020).

\section{CONCLUSIONS}

Through the analysis of the data from the focus group it is possible to highlight the perceptions of the specific needs in a garment that are different among the age groups of 'older' older women than 'younger' older women. It is important to highlight this item: women begin to accept the conditions of aging and declare themselves as elderly, from the age of 80 , also, the younger elderly do not yet perceive or have as a focus to notice the physical restrictions, in contrast, the older elderly daily experience the limitations arising from the aging process and worry about how to ease these restrictions. Young older women, besides considering themselves younger in their cognitive age, also perceive the existence of the distinction between clothes for old and young, while older women do not perceive it.

Besides, older women believe that getting older is part of life, because everyone ages, but younger women believe that "being old" depends a lot on their behavior, in the way they see and face life. Positive perceptions are associated with the fact that they can move around without restrictions, because they have dominion over their body and do not prioritize pain, in addition to holding themselves responsible for old age. These data show us the differences between the profiles of the same segment, the elderly, corroborating Moschis (2003), who reports the need to subdivide this niche to meet the specific needs of each sub-segment.

Regarding the inherent aspects of clothing consumption, older women buy clothes out of necessity stemming from the degradation of current pieces and it is analyzed through the low consumption of clothes, the intergenerational influence, in which these individuals followed the models and habits of their parents (Mittal; Royne, 2010), that is, the behaviors of parents were adopted and followed by them, reproducing generational characteristics of Baby Boomers.

The behavior of elderly consumers about the supply of clothing directed to their segment: elderly women notice the lack of clothing, and do not feel represented by current fashion, because they believe that this is made for young women, noting through the media and in the stores themselves; some elderly women report difficulties caused by physical limitations, needing help from other people to the act of dressing, reducing autonomy, therefore, feel the need for the sizes of the garments to be larger, this being another difficulty for the consumption of clothing. From this point on, although part of the elderly participants in the study have physical limitations, this condition cannot be generalized to the entire elderly population.

To conclude then, managentially, this research contributes for the organizations of the fashion sector that wish to invest in this market segment to obtain assertive information about the specific 
needs of elderly women. Besides being able to understand the need to give attention to the details of the elderly body, it is necessary to develop techniques that facilitate their handling. Another contribution, both for companies that wish to invest in this niche and those that do not have it as a target public but make purchases of pieces thinking about selling to these individuals, is the need to solve the inadequacies related to the sizes of the pieces, this being the problem most cited in the speeches analyzed, as well as in the distinction of the preferences regarding the design and aesthetics of the clothes for women, but with the main objective of meeting the needs of functionality, comfort and usability of the pieces.

The study contributes to the literature of consumer behavior, inserting itself in the gap of studies that aim to analyze the perceptions and behaviors of a target audience about the production of specific products. Also, it contributes to the results presented by Moschis (2003), in which many companies do not see the need to refer to the niche of elderly consumers differently from other segments, and still believe that consumers above a certain age belong to the same category, therefore, they should be treated similarly. It is clear from this article that perceptions of the more specific needs of an outfit are different among the older age group itself, i.e., it can be inferred that there is still a subdivision between the "older" and the "younger" elderly.

\section{References}

Abdel-Aty, M., Kitamura, R., \& Jovanis, P. (1997). Using stated preference data for studying the effect of advanced traffic information on drivers' route choice. Transportation Research Part C: Emerging Technologies, 5(1), 39-50. Doi: 10.1016/S0968-090X(96)00023-X

Amaro, L. E., \& Meira, P. R. (2012). Consumidores idosos: aspectos do seu comportamento de consumo. COLÓQUIO. Revista Cientifica Faccat, 6(1-2), 9-20.

Araújo, F. F. \& Rocha, A. (2013). Relações entre a população de terceira idade e o consumo de lazer: Convergências dos estudos existentes. 7ème Congrès de l'Institut Franco-Brésilien d'Administration des Entreprises. Institut d'Administration des Entreprises de l'Université François Rabelais de Tours.

$\mathrm{Au}$, J., Lam, J., \& Ho, C. (2016). Design preferences and experience of older people's choice in fashion in Hong Kong. International Journal of Fashion Design, Technology and Education, 9(3), 183-191. doi: 10.1080/17543266.2016.1154110

Ballstaedt, A. L. M. P. (2007). Comportamento e Estilo de Vida da População Idosa e seu Poder de Consumo. $2^{o}$ Encuentro Latinoamericano De Diseño. Buenos Aires: Facultad de Diseño y Comunicación, Universidad de Palermo.

Ballstaedt, A. L. M. P. (2008). População idosa: estilo e consumo de moda. 1o Colóquio Internacional De Moda, Novo Hamburgo: FEEVALE.

Barcelos, R. H., Esteves, P. S., \& Slongo, L. A. (2016). A consumidora da terceira idade: moda e identidade. International Journal of Business Marketing, 1(2), 003-018.

Baudot, François. (2002). Moda do século. São Paulo: Cosac \& Naify.

Bauer, M. W., \& Gaskell, G. (2017). Pesquisa qualitativa com texto, imagem e som: um manual prático. Editora Vozes Limitada.

Beauvoir, S. (1990). A velhice. Rio de Janeiro: Nova Fronteira.

Blackwell, R. D., Miniard, P. W. \& Engel, J. F. (2008). Comportamento do Consumidor. São Paulo: Cengage Learning.

Calixta, M., Afonso, T. \& Locatelli, R. L. (2011). Segmentação de mercado, diferenciação de produtos e a perspectiva da antropologia do consumo. Revista Gestão \& Tecnologia, 11(1), 106-122. Doi: 10.20397/2177-6652/2011.v11i1.276

Camarano, A. A. (2002). Envelhecimento da população brasileira. Texto para discussão, n. 858. Rio de Janeiro: IPEA.

Camarano, A. A. (org.). (2004). Os novos idosos brasileiros. Muito além dos 60 anos. Rio de Janeiro: Ipea.

Catellani, R. M. (2003). Moda ilustrada de A a Z. São Paulo: Manole. 
Castilhos, K. (2004). Moda e Linguagem. 1. ed. São Paulo: Anhembi Morumbi.

Cooper, D. R. \& Schindler, P. S. (2016). Métodos de Pesquisa em Administração. 12a Edição. McGraw Hill Brasil.

Côrte, B, Oliveira, B. \& Medeiros, S. (2006). Brasil: o que dizem os números sobre a pessoa idosa? 12ำ Encontro da Associação Brasileira de Estudos Populacionais. Campinas: Universidade Estadual de Campinas.

Creswell, J. W. W. (2010). Projeto de pesquisa: métodos qualitativo, quantitativo e misto. 2. ed. Porto Alegre: Bookman.

Da Silva, V. B. (2015). Seniors as a Strategic Public: The elderly consumer behavior in the region of Porto Alegre, RS. Brazilian Journal of Management \& Innovation, Caxias do Sul, RS, 2(2), 81-107, Doi: 10.18226/23190639.v2n2.04

Das Neves, É. P., Brigatto, A. C., \& Paschoarelli, L. C. (2015). Fashion and Ergonomic Design: Aspects that influence the perception of clothing usability. Procedia Manufacturing, 3, 6133-6139. Doi: 10.1016/j.promfg.2015.07.769

Debus, M. (1994). Manual para excelencia en la investigación mediante grupos focales. In: Manual para excelencia en la investigación mediante grupos focales. HealthCom.

Decreto de Lei no 10.741. (2003). Política Nacional do Idoso - Estatuto do Idoso. Diário Oficial da União (03-10-03), 183a da Independência, 115ª da República.

Dellarmelin, M. L., Balbinot, V. A., \& Froemming, L. M. S. (2017). Análise do comportamento e utilização das redes sociais pelos idosos. Revista Sociais e Humanas, 30(1), 174-184. Doi: $10.5902 / 2317175824669$

Dellarmelin, M. L.; Froemming, L. M. S. (2019). 0 Uso Da Tecnologia Assistiva em Produtos: Um Estudo Sobre Roupas para Consumidores Idosos. Revista Eletrônica Científica Inovação e Tecnologia (RECIT), Medianeira, 10(25), 46-71.

Embacher, A. F. (1999). Moda e identidade: a importância do vestuário do ponto de vista psicológico no processo de desenvolvimento da identidade de nível sócio-econômico A do sexo feminino. Tese (Doutorado). Programa de Pós-Graduação em Administração, Pontifícia Universidade Católica de São Paulo, São Paulo.

Fischer, M., Victer, C. G., \& Teixeira, C. (2009). Moda para Terceira Idade: concebendo uma coleção a partir do estudo de caso em uma Faculdade Sênior. 5ํ Congresso Internacional de Pesquisa em Design. Bauru: UNESP.

Flick, U. (2002). Qualitative research-state of the art. Social Science Information, 41(1), 5-24. Doi: $10.1177 / 0539018402041001001$

Flick, U. (2013). Introdução à pesquisa qualitativa. Porto Alegre: Penso.

Gomes, M. C., \& Lüdorf, S. M. A. (2009). Idoso, moda e sedentarismo: possíveis relações. Arquivos em Movimento, 5(2), 156-167.

Gonçalves, X. (2002). Donna: abc da moda. Porto Alegre: Zero Hora Editora Jornalística.

Gonzalez, A., \& Paliwoda, S. (2006). Segmenting the older consumer for online travel. The marketing review, 6(4), 331-348.

Holmlund, M., Hagman, A., \& Polsa, P. (2011). An exploration of how mature women buy clothing: empirical insights and a model. Journal of Fashion Marketing and Management: An International Journal. Doi: 10.1108/13612021111112377

Joung, H. M., \& Miller, N. J. (2006). Factors of dress affecting self-esteem in older females. Journal of Fashion Marketing and Management: An International Journal. Doi: $10.1108 / 13612020610701983$

Machado, A. H., Casarin, V. A., Miranda, R. L., Franco, M. B., Santos, A. V. \& Wbatuba, B. B. R. (2016). 0 comportamento de consumo de vestuário de um grupo de terceira idade: Estudo de caso em um Município do Estado do Rio Grande do Sul. Revista Espacios, 37(5).

Mittal, B., \& Royne, M. B. (2010). Consuming as a family: Modes of intergenerational influence on young adults. Journal of Consumer Behaviour, 9(4), 239-257. Doi: 10.1002/cb.315

Moschis, G. P. (1992). Gerontographics: a scientific approach to analyzing and targeting the mature market. Journal of Services Marketing. Doi: 10.1108/08876049210035890 
Moschis, G. P., \& Mathur, A. (2006). Older consumer responses to marketing stimuli: the power of subjective age. Journal of Advertising Research, 46(3), 339-346. Doi: $10.2501 / \mathrm{S} 0021849906060326$

Nam, J., Hamlin, R., Gam, H. J., Kang, J. H., Kim, J., Kumphai, P., Starr, C. \& Richards, L. (2007). The fashion-conscious behaviours of mature female consumers. International Journal of Consumer Studies, 31(1), 102-108. Doi: 10.1111/j.1470-6431.2006.00497.

Neder, V. (2005). 0 potencial de consumo da terceira idade. Jornal do Comércio. Recuperado em 15 fevereiro, 2005 de http://administradores.com.br/noticias/o-potencial-de-consumo-daterceira-idade

Nielsen, A. (2014). A diferença de idade: à medida que a população global envelhece suas necessidades não estão sendo satisfeitas. Rio de Janeiro, RJ: Nielsen.

Noy, C. (2008). Sampling knowledge: The hermeneutics of snowball sampling in qualitative research. International Journal of social research methodology, 11(4), 327-344. Doi: $10.1080 / 13645570701401305$

Paço, A., \& Raposo, M. (2003). Análise das atitudes de compra dos consumidores líderes e dos consumidores seguidores no caso do vestuário. XIII Jornadas Hispano-Lusas de Gestión Cientifica (65-74). Covilhã: Autor.

Palomino, E. (2002). A Moda. São Paulo: Publifolha.

Prodanov, L. S. \& Reinke, C. (2016). Mulher madura e o consumo de moda no brasil. Revista Prâksis, 1, (121-137). Doi: 10.25112/rp.v1i0.439

Schein, M., Perin, M. G., Sampaio, C. H., \& de Ugalde, M. M. (2009). O comportamento da compra de serviços de turismo na terceira idade. Turismo-visão e ação, 11(3), 341-357.

Slongo, L., Albrecht, C. F., Lavouras, D. F., Esteves, P. S., \& Barcelos, R. H. (2019). Moda para a consumidora da Terceira Idade. 33॰ Encontro da Associação Nacional de Pós-Graduação e Pesquisa em Administração. São Paulo: São Paulo. Recuperado em http://www.anpad.org.br/diversos/down_zips/45/MKT2769.pdf

SPC Brasil e Meu Bolso Feliz. (2014). Relatório - Análise Consumo da Terceira Idade. Bloco Renda, Consumo e Lazer.

Tilley, A. R. \& Dreyfuss, H. (2005). As medidas do homem e da mulher: fatores humanos em design. São Paulo: Bookman.

Twigg, J. (2007). Clothing, age and the body: a critical review. Ageing \& Society, 27(2), 285-305. Doi: $10.1017 / \mathrm{S} 0144686 \mathrm{X} 06005794$

Ugalde, M. \& Slongo, L. A. (2006). As emoções no processo decisório da Compra de Imóveis por Consumidores da Terceira Idade. Anais do 30 Encontro da Associação Nacional de Pós-Graduação e Pesquisa em Administração. Salvador: ANPAD. Recuperado em http://www.anpad.org.br/diversos/down_zips/10/enanpad2006-mktb-3186.pdf

Vianna, C., \& Quaresma, M. (2015). Ergonomia: conforto têxtil no vestuário do idoso. 15॰ Congresso Internacional de Ergonomia e Usabilidade de Interfaces Humano-Tecnologia, (1662-1670). Recuperado em

http://pdf.blucher.com.br.s3-sa-east-1.amazonaws.com/designproceedings/15ergodesign/231E144.pdf

Zhang, M., Andrew, S., Warnaby, G., \& Gill, S. (2016). Exploring the Impact of Lifestyle on Fashion Consumption Behaviour for Older Chinese Women. In: Advances in Ergonomics in Design (345357). Springer, Cham. Doi: 10.1007/978-3-319-41983-1_31 